\title{
Effect of antibody to transforming growth factor $\beta$ on bleomycin induced accumulation of lung collagen in mice
}

\author{
Shri N Giri, Dallas M Hyde, Mannfred A Hollinger
}

\begin{abstract}
Background-Increased production of transforming growth factor $\beta$ (TGF- $\beta$ ) seems to have an important role in the pathophysiology of bleomycin induced lung fibrosis. This is attributed to the ability of TGF- $\beta$ to stimulate infiltration of inflammatory cells and promote synthesis of connective tissue, leading to collagen deposition.

Methods-The study was designed to evaluate the antifibrotic potential of TGF- $\beta$ antibody in mice treated with bleomycin, which is a model of lung fibrosis. Under methoxyflurane anaesthesia, each mouse received intratracheally either $50 \mu 1$ sterile isotonic saline or 0.125 units bleomycin in $50 \mu 1$. Within five minutes after the instillation, mice received into the tail vein $100 \mu l$ non-immune rabbit IgG, TGF- $\beta_{2}$ antibody, or a combination of TGF- $\beta_{2}$ and TGF- $\beta_{1}$ antibodies at various dose regimens. Mice were killed 14 days after the instillation and their lungs processed for morphological and biochemical studies.
\end{abstract}

Results-Administration of $250 \mu \mathrm{g}$ of TGF- $\boldsymbol{\beta}_{2}$ antibody after instillation of bleomycin followed by $100 \mu \mathrm{g}$ on day 5 and $100 \mu \mathrm{g}$ on day 9 significantly reduced the bleomycin induced increases in the accumulation of lung collagen from $445 \cdot 8$ (42.3) $\mu$ g/lung to $336 \cdot 7$ (56.6) $\mu$ g/lung at 14 days. Similarly, the combined treatment with $250 \mu \mathrm{g}$ TGF- $\beta_{2}$ antibody and $250 \mu \mathrm{g}$ TGF- $\beta_{1}$ antibody after bleomycin instillation followed by $100 \mu \mathrm{g}$ of each antibody on day 5 also caused a significant reduction in bleomycin induced increases in lung collagen accumulation and myeloperoxidase activity at 14 days.

Conclusions-These results suggest that TGF- $\beta$ has an important role in the aetiology of bleomycin induced lung fibrosis; the neutralisation of TGF- $\beta$ by systemic treatment with its antibodies offers a new mode of pharmacological intervention which may be useful in treating lung fibrosis.

(Thorax 1993;48:959-966)
Interstitial pulmonary fibrosis is a potentially lethal, chronic response of the lung to injury that may result from a wide range of processes. $^{1}$ Regardless of its multifactorial origin, interstitial pulmonary fibrosis is invariably accompanied by an over exuberant repair process, which is characterised by an excessive number of fibroblasts, ${ }^{2}$ an absolute increase in lung collagen content, and abnormality in the ultrastructural appearance and spatial distribution of collagen types. ${ }^{3}$

Bleomycin represents a group of glycopeptides that are used as chemotherapy in the treatment of cancer. ${ }^{4}$ The use of bleomycin as an antineoplastic drug is, however, limited because it produces a dose dependent pneumonitis which often progresses to interstitial pulmonary fibrosis in humans. ${ }^{4}$ Intratracheal instillation of bleomycin in rodents is often used as an animal model of interstitial pulmonary fibrosis as it resembles that seen in humans. ${ }^{56}$

The number of cytokines known to upregulate the inflammatory and fibroproliferative responses of lungs leading to increased extracellular matrix production in the rodent bleomycin model of lung fibrosis is ever increasing. ${ }^{7-10}$ It is generally accepted that the increased production of transforming growth factor $\beta$ (TGF- $\beta$ ) is an important component in the pathophysiology of bleomycin induced lung fibrosis for the following reasons. Firstly, TGF- $\beta$ is a potent stimulator of extracellular matrix synthesis, although its effects on cell proliferation depend on the presence of other growth factors and culture conditions. ${ }^{11-13}$ Secondly, Raghu et al found that TGF- $\beta$ caused a twofold to fourfold increase in collagen production and collagen mRNA in fibroblasts cultured from normal and fibrotic human lungs. ${ }^{14}$ Thirdly, there is increased expression of TGF- $\beta$ gene and cell proliferation in lungs undergoing bleomycin induced pulmonary fibrosis. ${ }^{10} 1516$

In addition, Brockelmann et al found an abundant expression of TGF- $\beta_{1}$ mRNA in alveolar macrophages in lung tissue from patients with idiopathic pulmonary fibrosis. ${ }^{17}$ These investigators postulated that TGF- $\beta_{1}$ associated with the extracellular matrix of lung may provide a potent stimulus for the persistent expression of connective tissue 
genes followed by increased synthesis and deposition of collagen in lung, a hallmark of pulmonary fibrosis. Similarly, Khalil et al found a noticeable and consistent increase in TGF- $\beta$ production in epithelial cells and macrophages in sections of lung from patients with advanced idiopathic pulmonary fibrosis. ${ }^{18}$

We investigated the role of TGF- $\beta$ in the pathogenesis of bleomycin induced lung fibrosis by treatment with TGF- $\beta_{2}$ antibody or a combination of TGF- $\beta_{2}$ and TGF- $\beta_{1}$ antibodies at various dose regimens. We also investigated the effects of combined treatment with TGF- $\beta_{2}$ and TGF- $\beta_{1}$ antibodies on bleomycin induced increases in the lung myeloperoxidase and prolyl hydroxylase activities and lipid peroxidation as well as protein content and acid phosphatase activity of supernatant from bronchoalveolar lavage fluid.

\section{Methods}

All experiments were carried out in male albino Swiss-Webster mice weighing 28-30 g (Simonsen, Gilroy, California). Bleomycin sulphate was generously donated by the Bristol-Myers Company (Syracuse, New York), and antibodies to TGF- $\beta_{1}$ and TGF- $\beta_{2}$ were obtained from $R$ and $D$ Systems (Minneapolis, Minnesota). Chrom-Pure rabbit IgG was obtained from Jackson Immuno Research Laboratories (West Grove, Pennsylvania). L-3,4-[ $\left.{ }^{3} \mathrm{H}\right]-$ Proline (purity $98.5 \%$, specific activity $50.0 \mathrm{Ci} / \mathrm{mmol}$ ) was purchased from NEN Research Products (Boston, Massachusetts). L-4-[ $\left.{ }^{3} \mathrm{H}\right](\mathrm{G})-$ Hydroxyproline $(8 \mathrm{Ci} / \mathrm{mmol})$ was obtained from American Radiolabeled Chemicals (St Louis, Missouri). All other reagents were of analytical grade and obtained from standard commercial sources.

\section{STUDY DESIGN}

Mice were kept in plastic cages in groups of four in animal resource services facilities approved by the American Association for the Accreditation of Laboratory Animal Care and allowed to acclimatise for one week before the start of the experiments. Mice had free access to Rodent Laboratory Chow 5001 (Purina Mills, St Louis, Missouri) and water and were housed in a room with lighting cycle of 12 hours of light and 12 hours of dark. Animals were randomly assigned to four groups: (1) saline and non-immune rabbit IgG (SA + IgG); (2) bleomycin and nonimmune rabbit IgG (BL + IgG); (3) bleomycin and TGF- $\beta_{2}$ antibody (BL + TGF- $\beta_{2} \mathrm{Ab}$ ); and (4) bleomycin and TGF- $\beta_{2}$ and TGF- $\beta_{1}$ antibodies (BL + TGF- $\beta_{2}+$ TGF- $\beta_{1} \mathrm{Ab}$ ). Bleomycin sulphate was freshly dissolved in sterile isotonic saline and TGF- $\beta$ antibodies in phosphate buffered saline (sodium dihydrogen phosphate $10 \mathrm{mmol} / 1$ in $0.9 \%$ saline, $\mathrm{pH} 7 \cdot 2)$ and filtered $(0.2 \mu \mathrm{m}$ filter). The rabbit IgG was also dissolved in phosphate buffered saline and filtered in the same way.

\section{TREATMENT OF ANIMALS}

Under methoxyflurane anaesthesia mice in each group received intratracheally either $50 \mu \mathrm{l}$ sterile isotonic saline or $0 \cdot 125$ units of bleomycin solution in $50 \mu \mathrm{l}$, according to the procedure described by Raisfeld. ${ }^{19}$ Soon after intratracheal instillation mice in all groups received either non-immune rabbit IgG or TGF- $\beta$ antibodies in $100 \mu \mathrm{l}$ through the tail veins as follows: group 1 (SA + IgG) IgG $250 \mu \mathrm{g}$ within five minutes after saline instillation then $100 \mu \mathrm{g}$ on day 5 and $100 \mu \mathrm{g}$ on day 9; group 2 (BL + IgG) IgG $250 \mu \mathrm{g}$ within five minutes after bleomycin instillation then $100 \mu \mathrm{g}$ on day 5 and $100 \mu \mathrm{g}$ on day 9; group 3 (BL + TGF- $\left.\beta_{2} \mathrm{Ab}\right)$ TGF- $\beta_{2}$ antibody $250 \mu \mathrm{g}$ within five minutes after bleomycin instillation then $100 \mu \mathrm{g}$ on day 5 and $100 \mu \mathrm{g}$ on day 9 ; group 4 (BL + TGF- $\beta_{2}$ + TGF- $\beta_{1}$ Ab) TGF- $\beta_{2}$ antibody $250 \mu \mathrm{g}$ and TGF- $\beta_{1}$ antibody $250 \mu \mathrm{g}$ within five minutes after bleomycin instillation then $100 \mu \mathrm{g}$ of each antibody on day 5 . A separate group of mice received the same amount of nonimmune rabbit IgG protein as the amount of antibodies given to mice in group 4, thus serving as controls for mice in group 4.

Mice were killed either at 8 days or 14 days by an overdose of intraperitoneal pentobarbital $(120-130 \mathrm{mg} / \mathrm{kg})$ after intratracheal instillation of saline or bleomycin. The lungs from mice killed at 8 days were used only for measurement of hydroxyproline as an index of collagen accumulation, whereas lungs from mice killed at 14 days were used for analysis of bronchoalveolar lavage fluid and for morphological and biochemical studies.

\section{BRONCHOALVEOLAR LAVAGE}

Lung lavage was performed as previously described. ${ }^{20}$ Briefly, after cannulation of the trachea the lungs were lavaged with $5 \mathrm{ml}$ of isotonic saline, given in five aliquots of $1 \mathrm{ml}$. The saline was administered with a syringe through the cannula, the chest wall was gently massaged, and the fluid was withdrawn. The volume of the recovered fluid was measured in a graduated test tube and ranged from $70 \%$ to $96 \%$ of the total volume with a mean (SD) of $88 \%(9 \%)$. The fluid was centrifuged at $1500 \mathrm{~g}$ for 20 minutes at $4^{\circ} \mathrm{C}$. The resulting supernatant was collected and stored at $-20^{\circ} \mathrm{C}$ until measurement of protein content and acid phosphatase activity.

\section{PREPARATION OF LUNGS FOR}

\section{HISTOPATHOLOGY}

After lung lavage the thoracic cavity was opened and the heart and lungs were removed en bloc from the thoracic cavity. The lungs were fixed through the trachea at a pressure of $30 \mathrm{~cm} \mathrm{H}_{2} \mathrm{O}$ with cacodylate buffered glutaraldehyde-paraformaldehyde fixative (400 mOsm, $\mathrm{pH} 7 \cdot 4$ ), as described previously. ${ }^{21}$ The right cranial, right caudal, and left lobes were later cut in transverse slabs ( $2 \mathrm{~mm}$ thick). One slab from each lobe and faced blocks $\left(1 \mathrm{~cm}^{2}\right)$ were randomly selected and embedded in paraffin, cut in $7 \mu \mathrm{m}$ sections, and stained with haematoxylin and eosin 
MORPHOMETRY

We defined parenchymal lesions as a thickening of interalveolar septa due to oedematous swelling, inflammatory cells, or fibrosis associated with hyperplastic epithelial cells or to clusters of airway inflammatory cells, or both, in either the airways or the interstitium. Lesions were evaluated in a single section from each of the three sampled lobes. The volume density of lesion, $\mathrm{V}_{\mathrm{v}}$, was determined by point counting techniques using the formula $V_{V}=P_{P}=P_{N} / P_{T}$, where $P_{P}$ is the point fraction of $P_{N}$, the number of points hitting a lesion divided by $P_{T}$, and $P_{T}$ is the total number of points hitting the section. Because of the patchy distribution of lesions each section was systematically scanned at a final magnification of 45 times with a 42 point lattice test system until all fields (10-25 fields) in the section were evaluated. A mean volume density of the multifocal lesions within the total lung was obtained by averaging the $V_{v}$ values contributed by each lung lobe. The volume of parenchymal lesions within the total lung was calculated from the product of the displaced lung volume, the volume density of parenchyma per lung, and the mean volume density of the multifocal lesions within the total lung. ${ }^{21}$

\section{BIOCHEMICAL STUDIES}

Lungs of animals used for biochemical studies were perfused in situ through the right ventricle with ice cold isotonic saline $(20 \mathrm{ml})$ to wash out the blood from the pulmonary vasculature through an opening in the left auricle. The lobes were quickly dissected free of non-parenchymal tissue, dropped in liquid nitrogen for immediate freezing and stored at $-80^{\circ} \mathrm{C}$. Later the frozen lungs were thawed and homogenised in potassium chloride $0 \cdot 1$ $\mathrm{mol} / \mathrm{l}$ and TRIS $0.02 \mathrm{~mol} / \mathrm{l}$ with a Polytron homogeniser (Brinkmann Instruments, Westbury, New York). The final volume of the homogenate ranged between $3.3 \mathrm{ml}$ and $4.5 \mathrm{ml}$. Several aliquots of the homogenate were stored at $-80^{\circ} \mathrm{C}$ until measurement of various biochemical variables.

\section{HYDROXYPROLINE ASSAY}

To assay hydroxyproline concentration 0.125 $\mathrm{ml}$ of $50 \%$ cold trichloroacetic acid was added to $0.5 \mathrm{ml}$ of homogenate. After 20 minutes on ice samples were centrifuged, the supernatant discarded, and the precipitate hydrolysed in $1 \mathrm{ml}$ of hydrochloric acid 6 $\mathrm{mol} / \mathrm{l}$, overnight (18-20 hours) at $110^{\circ} \mathrm{C}$. To monitor recovery tritiated hydroxyproline $\left(1.5 \times 10^{5} \mathrm{dpm}\right)$ was added to each hydrolysed sample. The hydroxyproline content of the sample was measured by the technique of Woessner. ${ }^{22}$ The recovery of tritiated hydroxyproline ranged from $85 \%$ to $95 \%$, and it was used to correct the amount of hydroxyproline for each sample.

\section{MYELOPEROXIDASE ASSAY}

The myeloperoxidase activity of the lung homogenate was assayed according to the technique described by Goldblum et $a .^{23}$
Myeloperoxidase was extracted in $0.5 \%$ hexadecyltrimethylammonium bromide in phosphate buffer $50 \mathrm{mmol} / \mathrm{l}(\mathrm{pH} 6 \cdot 0)$. The samples were freeze thawed (20 minutes at $-70^{\circ} \mathrm{C}$ ) three times followed by homogenisation each time on ice with a Polytron. The homogenate was then centrifuged at $40000 \mathrm{~g}$ for 15 minutes and the resulting supernatant used to assay for the myeloperoxidase activity spectrophotometrically: $0 \cdot 1 \mathrm{ml}$ of the supernatant was mixed with $2.9 \mathrm{ml}$ of phosphate buffer $50 \mathrm{mmol} / 1(\mathrm{pH} 6.0)$ containing Odianisidine dihydrochloride $0.167 \mathrm{mg} / \mathrm{ml}$ and $0.0005 \%$ hydrogen peroxide in a final volume of $3 \mathrm{ml}$. The change in absorbance at $460 \mathrm{~nm}$ was recorded on a Varian 219 Cary spectrophotometer (Varian Instrument Group, Sugarland, Texas). One unit of myeloperoxidase activity was defined as the volume of supernatant that degraded $1 \mu \mathrm{mol}$ of peroxide per minute at $25^{\circ} \mathrm{C} .{ }^{24}$

\section{PROLYL HYDROXYLASE ASSAY}

Prolyl hydroxylase substrate (procollagen) was prepared from tibias obtained from 10 day old chick embryos. Twenty four tibias were incubated for eight hours in $6.2 \mathrm{ml}$ of Dulbecco's modified Eagle's medium (GIBCO, Santa Clara, California) containing $a, a^{\prime}$-dipyridyl $(150 \mu \mathrm{g} / \mathrm{ml})$ and $1 \mathrm{mCi}$ of $\mathrm{L}-$ $3,4-\left[{ }^{3} \mathrm{H}\right]$ proline. After incubation the tibias were rinsed in two changes of water before homogenising in $5 \mathrm{ml}$ of distilled deionised water. The homogenate was centrifuged at $4^{\circ} \mathrm{C}$ for 20 minutes at $3000 \mathrm{~g}$. The supernatant was dialysed at $4^{\circ} \mathrm{C}$ for 72 hours against several changes of water. The retentate was portioned in several aliquots and stored frozen at -80 to $-85^{\circ} \mathrm{C}$.

The method for prolyl hydroxylase assay was essentially the same as described by Hutton et al. ${ }^{25}$ The incubation mixture for the assay in a total volume of $2 \mathrm{ml}$ consisted of ferrous ammonium sulphate $(0 \cdot 1 \mathrm{mmol} / \mathrm{l})$, $a$-ketoglutaric acid $(0 \cdot 1 \mathrm{mmol} / \mathrm{l}),\left[{ }^{3} \mathrm{H}\right]$ proline procollagen $(100000 \mathrm{dpm})$, lung homogenate $(100 \mu \mathrm{l})$, ascorbic acid $(0.5 \mathrm{mmol} / \mathrm{l})$, and TRIS-hydrochloric acid buffer $(0 \cdot 1$ $\mathrm{mol} / \mathrm{l}, \mathrm{pH} 7 \cdot 8)$. The reaction was started by the addition of ascorbic acid and continued for 30 minutes at $37^{\circ} \mathrm{C}$ in a Dubnoff metabolic shaker. The reaction was stopped by adding $0.2 \mathrm{ml}$ of $50 \%$ trichloroacetic acid. The tritiated water of the reaction system was separated by vacuum distillation of the whole reaction mixture. A $1.0 \mathrm{ml}$ aliquot of tritiated water from each distillation was mixed in 15 $\mathrm{ml}$ of Tritosol and counted in a liquid scintillation counter (Beckman Model LS 5801). The counting efficiency of the system was $30-35 \%$. The enzyme assay was conducted under conditions giving linear release of product in relation to the amount of sample used and the time of incubation.

\section{MALONDIALDEHYDE ASSAY}

Duplicate aliquots of the whole homogenate were used to measure the steady state value of malondialdehyde as an index of lipid peroxidation according to the procedure described 
by Ohkawa et al. ${ }^{26}$ Briefly, the assay entailed mixing $0.2 \mathrm{ml}$ of homogenate, $0.2 \mathrm{ml}$ of $8.1 \%$ sodium dodecyl sulphate, $1.5 \mathrm{ml}$ of $20 \%$ acetic acid (adjusted to $\mathrm{pH} 3.5$ with sodium hydroxide), $1.5 \mathrm{ml}$ of $0.8 \%$ aqueous solution of thiobarbituric acid, and $0.6 \mathrm{ml}$ of distilled deionised water. The mixture was heated at $95^{\circ} \mathrm{C}$ for 60 minutes. After cooling $5 \mathrm{ml}$ of n-butanol was added and the mixture was shaken vigorously, followed by centrifugation at $2000 \mathrm{~g}$ for 10 minutes. The absorbance of the upper organic layer was read at $532 \mathrm{~nm}$ and compared with a standard curve with tetraethoxypropane.

\section{PROTEIN CONTENT AND ACID PHOSPHATASE ASSAY}

The protein content of the supernatant from bronchoalveolar lavage specimens was determined by the method of Lowry et al with bovine serum albumin as standard. ${ }^{27}$ The catalysed release of 4-nitrophenol was monitored spectrophotometrically to estimate acid phosphatase activity in the supernatant. ${ }^{28}$ Briefly, both volume $(0.5 \mathrm{ml})$ and concentration of the buffer substrate solution (sodium citrate $90 \mathrm{mmol} / \mathrm{l}$, 4-nitrophenyl phosphate $15.2 \mathrm{mmol} / \mathrm{l}, \mathrm{pH} 4.9$ ) were adjusted to compensate for the larger sample volume required $(0.5 \mathrm{ml})$. The remainder of the assay was performed as previously described. ${ }^{28}$

\section{STATISTICAL ANALYSIS}

The data are expressed as total lung contents to avoid the artifactual lowering of the values in bleomycin treated animals caused by the presence of proteins of extrapulmonary origin. ${ }^{29}$ All values are reported as the mean (SE) and analysed by Fisher's least significance difference comparison test. ${ }^{30} \mathrm{~A}$ value of $\mathrm{p} \leqslant 0.05$ was considered to be significant.
(6)

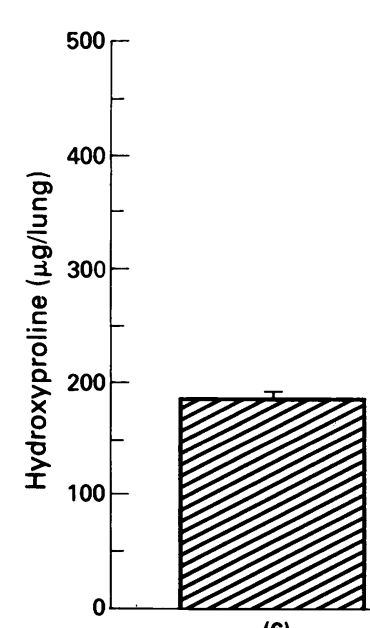

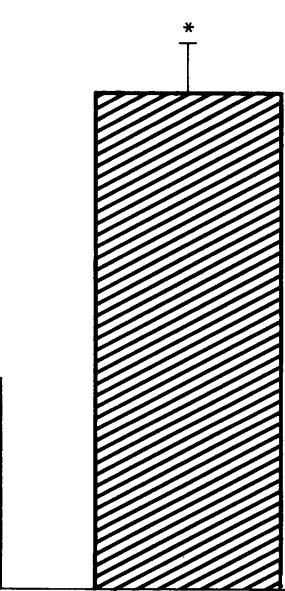

(6)

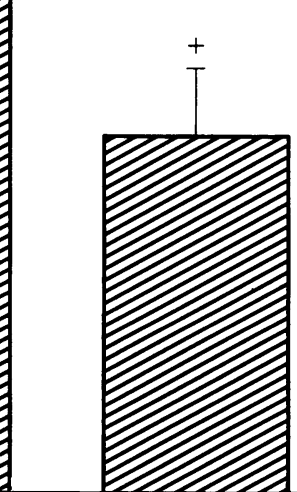

(5)
$B L+T G F-\beta A b$

Figure 1 Effect of TGF- $\beta_{2}$ antibody on bleomycin induced increases in lung hydroxyproline content. The number of animals in each group is shown in parentheses below each bar. $S A+I g G=$ saline + non-immune $I g G ; B L+I g G=$ bleomycin + nonimmune IgG; and $B L+T G F-\beta A b=$ bleomycin $+T G F-\beta_{2}$ antibody. Each value represents mean $(S E)$. *Significantly higher $(p<0.05)$ than other groups; + significantly lower $(p<0.05)$ than the $B L+I g G$ group.

\section{Results}

LUNG HYDROXYPROLINE CONTENT

The effects of intravenous administration of three consecutive doses of TGF- $\beta_{2}$ antibody on the bleomycin induced increase in lung collagen accumulation 14 days after bleo- mycin instillation are summarised in fig 1 . 을 The hydroxyproline content, an index of collagen accumulation, in the groups treated $\vec{\Rightarrow}$ : with bleomycin and IgG $(445.8 \quad(42 \cdot 3) \stackrel{\text { S }}{+}$ $\mu \mathrm{g} /$ lung) and bleomycin and TGF- $\beta_{2}$ antibody (336.7 (56.6) $\mu \mathrm{g} /$ lung) were significantly $\left(\mathrm{p}<\frac{}{\sigma}\right.$ 0.05 ) increased to $225 \%$ and $170 \%$ of the

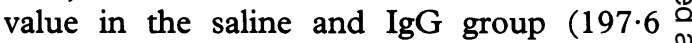
$(6 \cdot 1) \mu \mathrm{g} / \mathrm{lung})$, respectively. However, the treatment with TGF- $\beta_{2}$ antibody significantly $\vec{\circ}$ $(p<0.05)$ reduced the accumulation of lung collagen caused by intratracheal instillation of $\stackrel{\omega}{\sigma}$ bleomycin.

Since treatment with TGF- $\beta_{2}$ antibody $x$ alone did not completely block the bleomycin 9 induced increases in lung collagen accumula- $\vec{\circ}$ tion, we tested the effect of combined treat- of ment with TGF- $\beta_{2}$ and TGF- $\beta_{1}$ antibodies at various dose regimens. In a preliminary study treatment with one dose of TGF- $\beta_{2}$ antibody $\overrightarrow{0}$ $(100 \mu \mathrm{g})$ and TGF- $\beta_{1}$ antibody $(100 \mu \mathrm{g})$ administered via the tail vein within five minutes after intratracheal instillation of $\stackrel{\mathbb{\perp}}{-}$ bleomycin had no effect on bleomycin $\vec{\ominus}$ induced increases in the lung hydroxyproline $\omega$ content at 14 days. The hydroxyproline contents expressed as mean (SE)(n) were $192 \cdot 7$ 方 (9.6) (8), 350.2 (30.4) (11), and 369.1 $(30 \cdot 3)(8) \mu \mathrm{g} /$ lung in the groups $\mathrm{SA}+\mathrm{IgG}$, مै $\mathrm{BL}+\mathrm{IgG}$, and $\mathrm{BL}+\mathrm{TGF}-\beta_{2}+\mathrm{TGF}-\beta_{1}$ antibodies, respectively.

In the subsequent experiments TGF- $\beta_{2}$ 윽 and TGF- $\beta_{1}$ antibodies were administered in combination in the bleomycin treated mice at two doses. The first dose contained $250 \mu \mathrm{g}$ of TGF- $\beta_{2}$ antibody and $250 \mu \mathrm{g}$ of TGF- $\beta_{1}$ antibody administered intravenously within five minutes after instillation of bleomycin while the second dose contained only $100 \mu \mathrm{g}$ of each antibody and was administered at $5 \stackrel{2}{3}$ days. The mice were killed either at 8 or 14 days after intratracheal instillation. This regimen had no significant effect on the $\frac{T}{0}$ bleomycin induced increases in lung collagen accumulation at 8 days. The lung hydroxy- $\sigma$ proline contents were $207(14 \cdot 8)(5), 292 \cdot 3 \mathrm{~N}$ $(16 \cdot 8)(5)$, and $256(12 \cdot 0)(7) \mu \mathrm{g} / \mathrm{lung}$ in the groups $\mathrm{SA}+\mathrm{IgG}, \mathrm{BL}+\mathrm{IgG}$, and $\mathrm{BL}+\vec{\sigma}$ TGF- $\beta_{2}+$ TGF- $\beta_{1}$ antibodies, respectively. 0 However, the same regimen of treatment sig- $\bar{\Phi}$ nificantly attenuated the bleomycin induced $\stackrel{?}{+}$ increases in the lung collagen accumulation at 14 days (fig 2 ).

OTHER BIOCHEMICAL DETERMINANTS

Treatment with TGF- $\beta_{2}$ and TGF- $\beta_{1}$ antibodies in combination caused a significant $\delta$ attenuation of the bleomycin induced increase in lung myeloperoxidase activity at 14 days (fig 3). However, the significant $(p<0.05)$ increases in lipid peroxidation and prolyl hydroxylase activity of the lung and in protein content of the supernatant of 


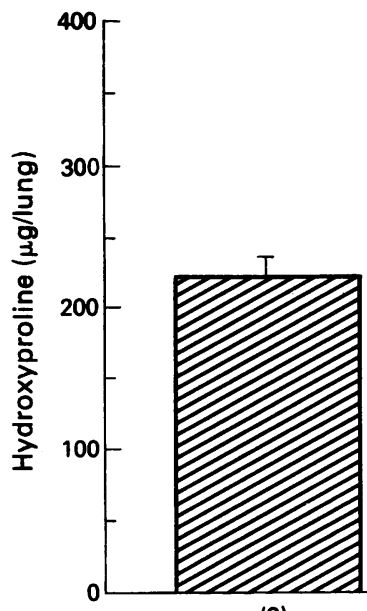

(9)

$S A+\lg G$

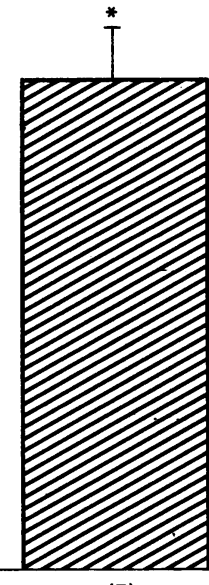

(5)

$B L+\lg G$

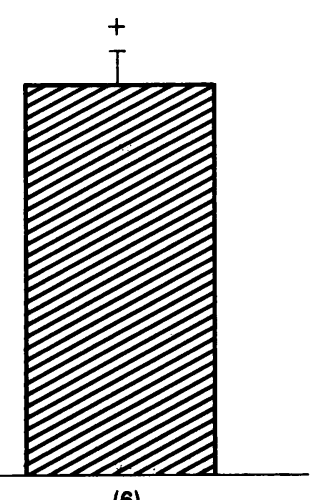

(6)

$B L+T G F-\beta A b$

Figure 2 Effect of combined treatment with TGF- $\beta_{2}$ and TGF- $\beta_{1}$ antibodies on bleomycin induced increases in lung hydroxyproline content. Saline (SA) or bleomycin (BL, $0 \cdot 125$ unit/mouse) was instilled intratracheally in $50 \mu l$ under methoxyflurane anaesthesia. Soon after instillation each mouse in the saline treated group received nonimmune IgG $500 \mu \mathrm{g}$ and thereafter $200 \mu \mathrm{g}$ on day 5. Each mouse in the bleomycin treated group received either non-immune IgG $500 \mu \mathrm{g}$ after instillation and thereafter $200 \mu \mathrm{g}$ on day 5 or $T G F-\beta_{2}(250 \mu g)+T G F-\beta_{1}(250 \mu g)$ antibodies after instillation and thereafter $100 \mu \mathrm{g}$ of each antibody on day 5. Mice were killed at 14 days after instillation and their lungs processed for hydroxyproline measurement. See the legend to figure 1 for other details and for explanation of abbreviations except that $B L+T G F-\beta A b=$ bleomycin $+T G F-\beta_{2}$ antibody $+T G F-\beta_{1}$ antibody. Each value represents mean (SE). *Significantly higher $(p<0.05)$ than other two groups; + significantly lower $(p<0.05)$ than the $B L+I g G$ group.

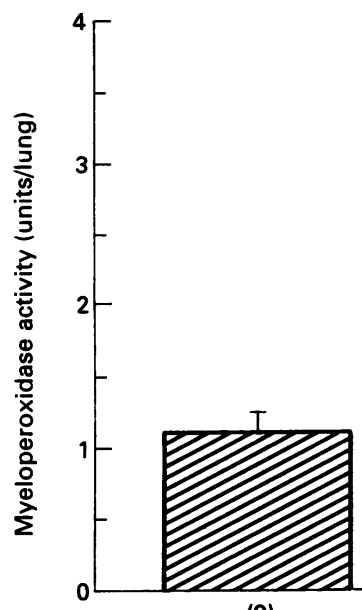

(9)

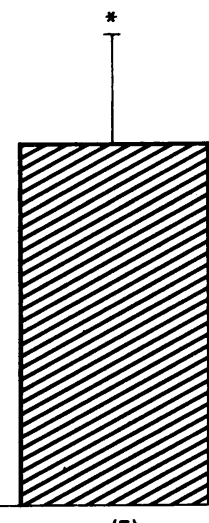

(5)

$\mathrm{BL}+\lg \mathrm{G}$

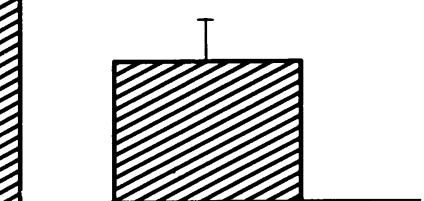

(6)

Figure 3 Effect of combined treatment with TGF- $\beta_{2}$ and TGF- $\beta$, antibodies on bleomycin induced increases in lung myeloperoxidase activity. Treatment schedule was the same as described in legend to figure 2. Mice were killed at 14 days after instillation. See the legend to figure 1 for other details and for explanation of abbreviations except that $B L+T G F-\beta A b=$ bleomycin $+T G F-\beta_{2}+T G F-\beta_{1}$ antibodies. Each value represents mean $(S E)$. *Significantly higher $(p<0.05)$ than other two groups.

bronchoalveolar lavage fluid in the group treated with bleomycin and IgG were not attenuated by the combined treatment with TGF- $\beta_{2}$ and TGF- $\beta_{1}$ antibodies at 14 days (table).

\section{HISTOPATHOLOGY AND MORPHOMETRY}

Histopathological and morphometric evaluations of lungs were carried out only in mice sacrificed at 14 days after intratracheal instillation of saline or bleomycin. The mice treated with saline and IgG in group 1 had no visible lesions and interalveolar septa with a normal thin appearance (fig $4 \mathrm{~A}$ ). In contrast, mice treated with bleomycin and IgG had lesions varying from multifocal locations in proximal acini to a diffuse distribution that occasionally involved the pleura. In diffuse lesions alveolar spaces were often obliterated by organised connective tissue. In the multifocal lesion interalveolar septa were thickened and lined by hypertrophied and hyperplastic cuboidal epithelial cells and abundant airway inflammatory cells (fig 4B). The mean (SD) volume of lung lesions in four mice of this group was $373 \cdot 8(56 \cdot 6) \mathrm{mm}^{3}$. Although mice treated with bleomycin and TGF- $\beta_{2}$ antibody showed similar lesions, the lesions seemed to contain more mononuclear inflammatory cells and less organised connective tissue and the lesions were not as diffuse and consolidated as seen in mice treated with bleomycin and IgG (fig 4C). The mean volume of lung lesions in two mice of this group was 283.8 $(146.0) \mathrm{mm}^{3}$, but it was not significantly different between these two groups because of the variance from animal to animal within groups and the small sample numbers.

Mice treated with saline and IgG receiving a total dose of $700 \mu \mathrm{g} \mathrm{IgG}$ also had no visible lesions and interalveolar septa had a normal thin appearance. Mice given bleomycin and IgG at a total dose of $700 \mu \mathrm{g}$ IgG had lesions similar to that described earlier (fig 4B). The volume of lung lesions in four mice of this group averaged $331.0(57.7) \mathrm{mm}^{3}$. Generally, in mice treated with bleomycin and the two TGF- $\beta$ antibodies the lesions were found in small foci in proximal acini. Lesions were composed primarily of hyperplastic epithelial cells and abundant mononuclear inflammatory cells with little fibrosis (fig 4D). The volume of the lesions in four mice of this group averaged $153.9(94 \cdot 1) \mathrm{mm}^{3}$. Although mice treated with bleomycin and a combination of TGF- $\beta_{2}$ and TGF- $\beta_{1}$ antibodies showed a

Effects of antibodies to TGF- $\beta_{2}$ and TGF- $\beta_{1}$ on bleomycin induced increases in malondialdehyde content and prolyl hydroxylase activity of lungs and on protein content and acid phosphatase activity of bronchoalveolar lavage fluid supernatant in mice

\begin{tabular}{lllll}
\hline & & & Supernatant from bronchoalveolar lavage \\
\cline { 3 - 5 } Treatment group & $\begin{array}{l}\text { Malondialdehyde } \\
(\text { nmol/lung) }\end{array}$ & $\begin{array}{l}\text { Prolyl hydroxylase } \\
(\text { dpm/lung/30 min) }\end{array}$ & $\begin{array}{l}\text { Acid phosphatase } \\
(\text { nmolllung/h) }\end{array}$ & $\begin{array}{c}\text { Protein } \\
(\mu g / l u n g)\end{array}$ \\
\hline SA + IgG $(\mathrm{n}=9)$ & $28 \cdot 5(1 \cdot 7)$ & $46403(900)$ & $149 \cdot 2(43 \cdot 0)$ & $454(60)$ \\
BL + IgG $(\mathrm{n}=5)$ & $51 \cdot 5(3 \cdot 8)^{\star}$ & $57902(4050)^{\star}$ & $321 \cdot 6(111 \cdot 8)$ & $3617(770)^{\star}$ \\
BL + TGF- $\beta$ Ab $(\mathrm{n}=6)$ & $43 \cdot 0(4 \cdot 6)$ & $52751(1532)$ & $200 \cdot 0(81 \cdot 5)$ & $3060(493)$ \\
\hline
\end{tabular}

^Significantly higher $(p<0.05)$ than SA + IgG group but not BL + TGF- $\beta$ Ab group. 

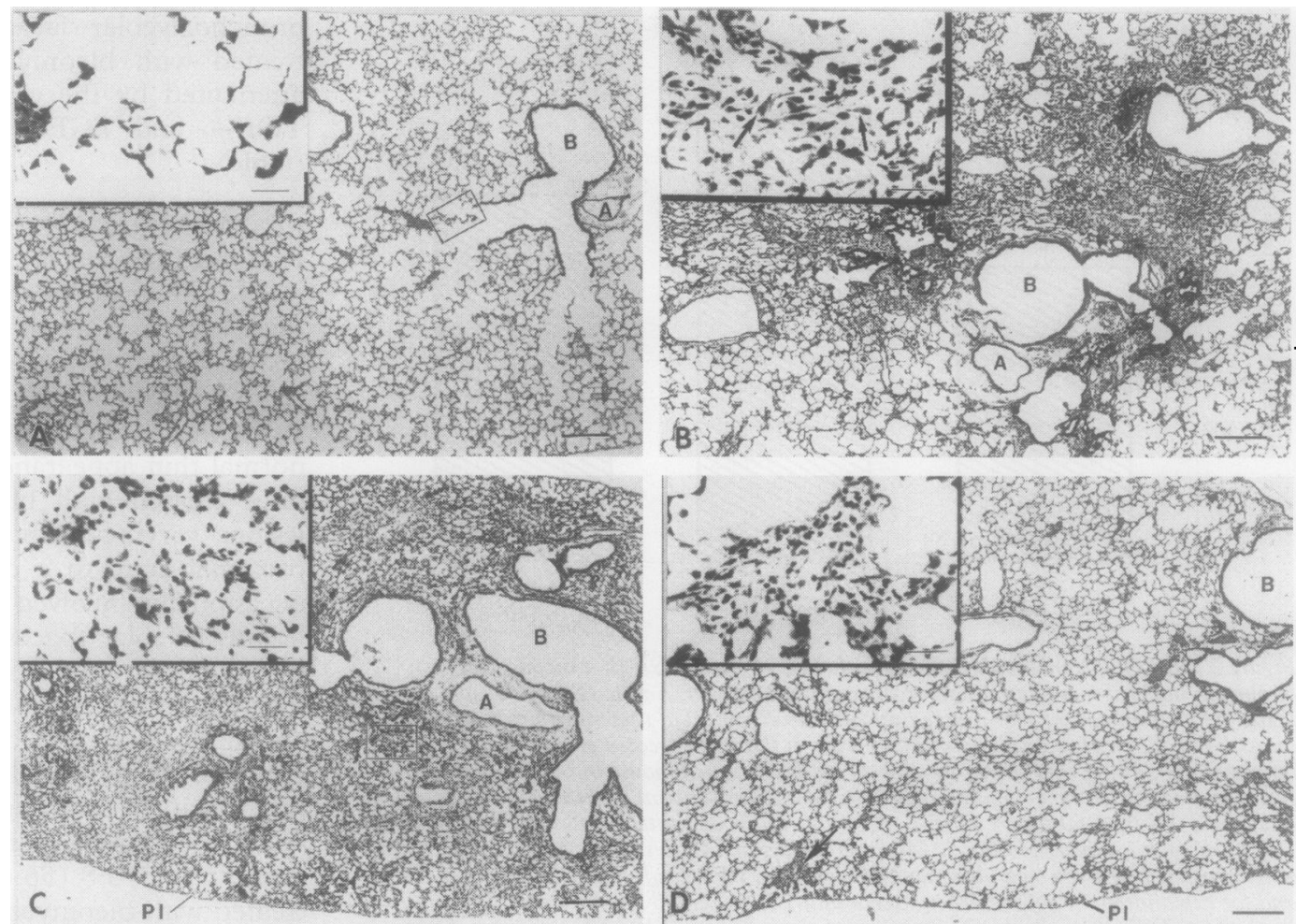

Figure 4 Effects of treatment with TGF- $\beta_{2}$ antibody or with TGF- $\beta_{2}$ and TGF- $\beta_{1}$ antibodies on bleomycin induced parenchymal lesions of mouse lung. The lungs were processed for histopathological study for each treatment group at 14 days after intratracheal instillation. (A) Representative micrograph from a saline + IgG treated mouse lung shows thin interalveolar septa and lack of any aggregation of inflammatory cells in alveolar spaces or the interstitium. Inset from proximal alveolar duct shows thin septa and septa tips. See the legend to figure 1 for treatment details. (B) Representative micrograph from a bleomycin $+I g G$ treated mouse lung shows regions of interstitial and alveolar fibrosis, thick septa lined by cuboidal epithelium, and periarterial and perivenular fibrosis. Inset from a consolidated area shows fibroblasts with prominent cytoplasmic staining (arrows). See legend to figure 2 for treatment details. (C) Representative micrograph from a bleomycin $+T G F-\beta_{2}$ antibody treated mouse shows lesions composed primarily of alveolar and interstitial mononuclear inflammatory cells. Inset in the centre of a lesion shows abundant mononuclear cells and few fibroblasts. See legend to figure 1 for treatment details. (D) Representative micrograph of lung from a mouse treated with bleomycin + TGF- $\beta_{2}$ antibody + TGF- $\beta_{1}$ antibody shows normal parenchyma except for a focus of interstitial fibrosis (arrow). Inset marked by the arrows is in the centre of a lesion and shows a mixture of mononuclear cells and fibroblasts. See legend to figure 2 for treatment details. $B=$ bronchus, $P l=$ pleural surface, $V=$ vein, $A=$ artery. Bars $=200 \mu \mathrm{m}$, inset bars $=30 \mu \mathrm{m}$.

$46 \%$ reduction in the volume of lung lesions compared with the mice given bleomycin and IgG $(78 \%$ reduction in the case of one mouse), there was no significant difference between the two groups because of a large variation from mouse to mouse.

\section{Discussion}

Our results are evidence that TGF- $\beta$ has an important role in the pathogenesis of lung fibrosis induced by intratracheal instillation of bleomycin in mice. This is based on the finding that intravenous administration of three consecutive doses of TGF- $\beta_{2}$ antibody in group 3 caused an appreciable reduction in the increased accumulation of lung collagen in bleomycin treated mice. Similarly, the combined treatment with TGF- $\beta_{2}$ and TGF$\beta_{1}$ antibodies also caused a significant reduction in bleomycin induced increases in lung collagen accumulation at 14 days after instillation. Morphometric evaluations suggested a reduction in the volume of parenchymal lesions in bleomycin treated animals after the combined treatment of TGF- $\beta_{2}$ and TGF- $\beta_{1}$ antibodies, but this difference was not significant.

The beneficial effect of TGF- $\beta_{2}$ and TGF$\beta_{1}$ antibodies in minimising the lung collagen accumulation and the severity and extent of the pulmonary fibrotic lesions depends on the dose and the duration of the study. One single dose of the combined antibodies administered in smaller amount $(100 \mu \mathrm{g}$ each) had no effect at 14 days, whereas a higher amount $(250 \mu \mathrm{g}$ each) administered soon 0 after bleomycin and thereafter in a smaller amount $\left(100 \mu \mathrm{g}\right.$ each) at five days caused a $\frac{T}{0}$ marked reduction in the lung collagen accumulation and the severity and extent of the $O$ fibrotic lesions at 14 days but not at 8 days $N$ after intratracheal instillation of bleomycin.

An excessive production of TGF- $\beta$ has $O$ been reported in lung tissue from patients 0 with idiopathic pulmonary fibrosis ${ }^{17} 18$ and $\overparen{D}$ other fibroproliferative diseases including $\stackrel{\text { ? }}{+}$ mesangial glomerulonephritis. ${ }^{31}$ A dramatic $\frac{T}{O}$ attenuation of the histological manifestation

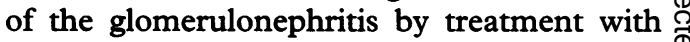

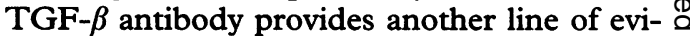
dence for a central role of TGF- $\beta$ in the fibrotic processes. $^{31}$ It is interesting that 8 Piguet et al have applied a similar approach to define the role of tumour necrosis factor in lung fibrosis induced by silica and bleomycin; treatment with antibody to the factor prevented lung fibrosis in both cases. ${ }^{32} 33$

Although the type of cells responsible for an increased expression of TGF- $\beta$ is not 
known in bleomycin induced fibrosis in mice, it could be fibroblasts, infiltrating monocytes or macrophages, or both, or other cell types. The most likely source of TGF- $\beta$ is probably macrophages. In rats the cell type responsible for an increased expression of TGF- $\beta$ seems to vary with the time after bleomycin treatment. ${ }^{9}$ Immunohistochemical staining of TGF- $\beta$ is greatest in intensity in bronchial epithelial cells up to 4 days, while macrophages show the greatest staining intensity from 4 to 7 days, and thereafter the staining of TGF- $\beta$ is localised in macrophages organised in clusters. Recently, Khalil et al localised TGF- $\beta$ in epithelial cells and alveolar macrophages of lung tissue from patients with advanced idiopathic pulmonary fibrosis ${ }^{18}$ and Brockelmann et al found a persistent expression of TGF- $\beta_{1}$ mRNA in alveolar macrophages in lung from patients with idiopathic pulmonary fibrosis. ${ }^{17} \mathrm{~A}$ local release of TGF- $\beta$ from macrophages in response to intratracheal instillation of bleomycin might initiate focal accumulation of fibroblasts and collagen deposition, and TGF- $\beta$ may also act directly on fibroblasts, increasing their numbers or rate of collagen secretion, or both. In addition, overproduction of TGF- $\beta$ in mice given bleomycin might be responsible for changes in the surrounding epithelial cells, including a reversible inhibition of their proliferation as seen for hepatocytes after partial hepatectomy in rats. ${ }^{34}$

The lung toxicity of bleomycin is associated with an increased sequestration of neutrophils, ${ }^{35}$ which is measured by myeloperoxidase activity in the lung ${ }^{23}$; increased lipid peroxidation, measured by the lung content of malondialdehyde ${ }^{35}$; increased lung prolyl hydroxylase activity, ${ }^{37}$ an enzyme responsible for post-translational modification of collagen before its maturation; and increased pulmonary vascular permeability, measured by the amount of extravasated plasma proteins $\mathrm{s}^{35}$ and increased acid phosphatase activity ${ }^{35}$ in the supernatant of bronchoalveolar lavage fluid. In our study mice treated with bleomycin and IgG had significantly higher lung myeloperoxidase and prolyl hydroxylase activities and malondialdehyde content and also a higher concentration of protein in the supernatant than mice treated with saline and IgG in the control group. These findings are consistent with the earlier findings and support the hypothesis that generation of reactive oxygen species is involved in bleomycin induced lung toxicity.

Other biochemical markers for evaluating the antifibrotic potential of exogenously administered compounds in the rodents with lung fibrosis include lipid peroxidation, prolyl hydroxylase, and myeloperoxidase activities in lungs and protein content and acid phosphatase activity in the supernatant of bronchoalveolar lavage fluid. ${ }^{37}$ Interestingly, systemic treatment with high doses of TGF$\beta_{2}$ and TGF- $\beta_{1}$ antibodies caused an appreciable reduction in lung myeloperoxidase activity 14 days after intratracheal instillation of bleomycin but had only marginal attenuat- ing effect on other biochemical determinants. This suggests that treatment with these antibodies does not diminish the ability of bleomycin to generate reactive oxygen species.

Myeloperoxidase contains haeme and is primarily present in the azurophilic granules of neutrophils. ${ }^{38}$ The activity of this enzyme in the lung is used as an index of intrapulmonary sequestration of neutrophils. ${ }^{23}$ Several laboratories including our own have shown the sequestration of neutrophils in the lungs of bleomycin treated animals. ${ }^{35}$ It has been postulated that excessive accumulation of neutrophils in vascular, interstitial, and alveolar spaces would inflict lung injury by generating reactive oxygen species and releasing proteolytic enzymes and myeloperoxidase. ${ }^{39}$ Myeloperoxidase released from neutrophils is known to oxidise chloride ions to hypochlorous acid ( $\mathrm{HOCl}$ ) in a reaction with hydrogen peroxide. ${ }^{40}$ Hypochlorous acid is biocidal as it immediately oxidises biologically important constituents of cells, including carbohydrates, nucleic acids, peptide linkages, and causes depletion of cellular NAD and ATP, leading to cell death. ${ }^{41}$ Recently, we reported that dermal application of nitroglycerine not only decreased the bleomycin induced increase in lung myeloperoxidase activity but also minimised lung toxicity. ${ }^{42}$ The results reported here are consistent with the findings of the above study as treatment with high doses of TGF- $\beta_{2}$ and TGF- $\beta_{1}$ antibodies caused a reduction in both the bleomycin induced increase in lung collagen accumulation and myeloperoxidase activity. Neutralisation of TGF- $\beta_{2}$ and TGF$\beta_{1}$ by systemic treatment with their antibodies in bleomycin instilled mice may minimise not only their stimulant effect on connective tissue growth in the lung but also their potent chemoattractant effect for polymorphonuclear leucocytes. ${ }^{43}$

Regardless of the mechanisms, it is clear that reduction of bleomycin induced increase in lung collagen accumulation by treatment with either TGF- $\beta_{2}$ antibody or TGF- $\beta_{2}$ and TGF- $\beta_{1}$ antibodies indicates the importance of TGF- $\beta$ in the regulation of extracellular matrix in lung fibrosis. This suggests that TGF- $\beta$ may have a similar role in the aetiology of lung fibrosis as found for glomerulonephritis, ${ }^{31}$ and its neutralisation by systemic treatment with its antibody offers a new approach to treating lung fibrosis.

This study was supported by a grant from the National Heart, Lung and Blood Institute of the National Institutes of Health (No 2 RO1 HL-27354). We thank Dr Qingiian Wang, Ms Mary J Schiedt, and Ms Mary Y Stovall for their expert technical help.

1 Crouch E. Pathobiology of pulmonary fibrosis. Am $\mathrm{f}$ Physiol 1990;259:L159-84.

2 Chandler DB, Hyde DM, Giri SN. Morphometric estimates of infiltrative cellular changes during the development of bleomycin-induced pulmonary fibrosis in hamsters. Am $\mathcal{F}$ Pathol 1983;112:170-7.

3 Clark JG, Kuhn C, McDonald JA, Mecham RP. Lung connective tissue. International Review of Tissue Research 1983;10:249-330.

4 Crooke ST, Brander WT. Bleomycin, a review. 7 Med 1976;7:333-427.

5 Snider GL, Celli BR, Goldstein RH, O'Brien JJ, Lucy EC. 
Chronic interstitial pulmonary fibrosis produced in hamsters by endotracheal bleomycin. Am Rev Respir Dis 1978;117:289-97.

6 Giri SN. Pharmacologic perspectives in pulmonary fibrosis research. In: Hollinger MA, ed. Focus on pulmonary pharmacology and toxicology. Boca Raton, Florida: CRC, 1990;2:19-55.

7 Jordana M, Richards C, Irving LB, Gauldie J. Spontaneous in vitro release of alveolar-macrophage cytokines after the intratracheal instillation of bleomycin in rats. Characterization and kinetic studies. $\mathrm{Am}$ Rev Respir Dis 1988;137:1135-40.

8 Suwabe A, Takahashi K, Yasui S, Arai S, Sendo F. Bleomycin-stimulated hamster alveolar macrophages release interleukin-1. Am $\mathcal{F}$ Pathol 1988;132:512-20.

9 Khalil N, Bereznay O, Sporn M, Greenberg AH. Macrophage production of transforming growth factor $\beta$ and fibroblast collagen synthesis in chronic pulmonary inflammation. $\mathcal{F}$ Exp Med 1989;170:727-37.

10 Phan SH, Kunkel SL. Lung cytokine production in bleomycin-induced pulmonary fibrosis. Exp Lung Res 1992;18:29-43.

11 Roberts AB, Sporn MB, Assoian RK, Smith JM, Roche NS, Wakefield LM, et al. Transforming growth factor type $\beta$ : rapid induction of fibrosis and angiogenesis in vivo and stimulation of collagen formation in vitro. Proc Natl Acad Sci USA 1986;83:4167-71.

12 Sporn MB, Roberts AB, Wakefield LM, Assoian RK. Transforming growth factor $\beta$ : biological function and chemical structure. Science 1986;233:532-4.

13 Ignotz RA, Massague J. Transforming growth factor- $\beta$ stimulates the expression of fibronectin and collagen and their incorporation into the extracellular matrix. f Biol Chem 1986;261:4337-42.

14 Raghu G, Masta S, Meyers D, Narayanan AS. Collagen synthesis by normal and fibrotic human lung fibroblasts and the effect of transforming growth factor- $\beta$. Am Rev Respir Dis 1989;140:95-100.

15 Hoyt DG, Lazo JS. Alterations in pulmonary mRNA encoding procollagens, fibronectin and transforming growth factor- $\beta$ precede bleomycin-induced pulmonary fibrosis in mice. $\mathcal{F}$ Pharmacol Exp Ther 1988;246:765-71.

16 Raghow R, Irish P, Kang AH. Coordinate regulation of transforming growth factor $\beta$ gene expression and cell proliferation in hamster lungs undergoing bleomycin-
induced pulmonary fibrosis. f Clin Invest 1989;84: 1836-42.

17 Brockelmann TJ, Limper AH, Colby TV, McDonald JA. Transforming growth factor beta 1 is present at sites of extracellular matrix gene expression in human pulmonary fibrosis. Proc Natl Acad Sci USA 1991;88: $6642-6$

18 Khalil N, O'Conner RN, Unruh HW, Warren PW, Flanders KC, Kemp A, et al. Increased production and immunohistochemical localization of transforming growth factor- $\beta$ in idiopathic pulmonary fibrosis. $A m \mathcal{F}$ Respir Cell Mol Biol 1991;5:155-62.

19 Raisfeld IH. Pulmonary toxicity of bleomycin analogs. Toxicol Appl Pharmacol 1980;56:326-36.

20 Girl SN, Hollinger MA, Schiedt MJ. The effects of paraquat and superoxide dismutase on pulmonary vascular permeability and edema in mice. Arch Environ Health 1981;36:149-54.

21 Nakashima JM, Hyde DM, Giri SN. Effects of a calmodulin inhibitor on bleomycin-induced lung inflammation in hamsters. Biochemical morphometric and bronchoalveolar lavage data. Am F Pathol 1986;124:528-36.

22 Woessner JF Jr. The determination of hydroxyproline in tissue and protein samples containing small proportions of this imino acid. Arch Biochem Biophys 1961:93:440-7.

23 Goldblum SE, Wu K-M, Jay $M$. Lung myeloperoxidase as a measure of pulmonary leukostasis in rabbit. $f$ Appl Physiol 1985;59:1978-85.
24 Worthington Biochemical Corporation. Peroxidase. In: Worthington enzyme manual. Freehold, New Jersey: Worthington Biochemical Corporation, 1972:43-5.

25 Hutton J Jr, Tappel AL, Udenfriend S. A rapid assay for collagen proline hydroxylase. Anal Biochem 1966;16: 384-94.

26 Ohkawa H, Ohismi N, Yagi K. Assay for lipid peroxides in animal tissues by thiobarbituric acid reaction. Anal Biochem 1979;95:351-8.

27 Lowry OH, Rosebrough NJ, Farr AL, Randall RJ. Protein measurement with the Folin Phenol reagent. I Biol Chem 1951;193:265-75.

28 Moss DW. Acid phosphatases. In: Bergmeyer HU, $\Rightarrow$ Bergmeyer J, Grasse M, eds. Methods of enzymatic analysis. Deerfield Beach, Florida: Chemie Verlag, 1983: 92-106

29 Karlinski JB, Goldstein CH. Fibrotic lung diseases: a perspective. F Lab Clin Med 1980;96:939-42.

30 SAS Institute. SAS/STAT guide for personal computers. Cary, North Carolina: SAS Institute, 1985.

31 Border WA, Okuda S, Languino LR, Sporn MB, Rouslahti E. Suppression of experimental glomerulonephritis by antiserum against transforming growth factor $\beta_{1}$. Nature 1990;346:371-4

32 Piguet PF, Collart MA, Grau GE, Sappino AP, Vassalli P. Requirement of tumor necrosis factor for development of silica-induced pulmonary fibrosis. Nature 1990;344: 245-7.

33 Piguet PF, Collart MA, Grau GE, Kapanci Y, Vassalli P. Tumor necrosis factor/cachectin plays a key role in bleomycin-induced pneumopathy and fibrosis. I Exp Med 1989;170:655-63.

34 Russell WE, Coffey RJ Jr, Oullette AJ, Moses HL. Type $\beta$ G transforming growth factor reversibly inhibits the early proliferative response to partial hepatectomy in the rat. Proc Natl Acad Sci USA 1988;85:5126-30.

35 Giri SN, Hyde DM, Nakashima JM. Analysis of bronchoalveolar lavage fluid from bleomycin-induced pulmonary fibrosis in hamsters. Toxicol Pathol 1986;14: 149-57

36 Giri SN, Chen ZL, Younker WR, Schiedt MJ. Effects of intratracheal administration of bleomycin on GSHshuttle enzymes, catalase, lipid peroxidation and collagen content in the lungs of hamsters. Toxicol Appl Pharmacol 1983;71:132-41.

37 Wang Q, Giri SN, Hyde DM, Li C. Amelioration of bleomycin-induced pulmonary fibrosis in hamsters by combined treatment with taurine and niacin. Biochem Pharmacol 1991;42:1115-22.

38 Kinkade JM, Pember SO, Barnes KC, Shapiro R, Spitznagel JK, Martin LE. Differential distribution of distinct forms of myeloperoxidase in different azuro-philic granule subpopulations from human neutrophils. Biochem Biophys Res Commun 1983;114:296-303.

39 Weiss SJ. Tissue destruction by neutrophils. N Engl f Med $\underset{?}{\mathcal{F}}$ 1989;320:365-76

40 K'ebanoff SJ. Phagocytic cells: production of oxygen metabolism. In: Gallin JI, Goldstein IM, Snyderman R, eds. Inflammation: basic principles and clinical correlates. New York: Raven Press, 1988:391-44.

41 Dallegri F, Goretti R, Ballestrero A, Ottonello L, Patrone F. Neutrophil-induced depletion of adenosine triphosphate in target cells: evidence for a hypochlorous acidmediated process. F Lab Clin Med 1988;112:765-72.

42 Wang Q, Haynam DR, Hyde DM, Combs AB, Giri SN. Reduction of bleomycin-induced sequestration of neutrophils and vascular injury in hamster lungs by nitroglycerine. Inflammopharmacology 1992;1:249-61.

43 Reibman J, Meixler S, Lee TC, Gold LI, Cronstein BN, O Haines KA, et al. Transforming growth factor beta I, a potent chemoattractant for human neutrophils, bypasses $N$ classical signal-transduction pathways. Proc Natl Acad Sci USA 1991;88:6805-9. 